Tropical Journal of Pharmaceutical Research June 2020; 19 (6): 1185-1190

ISSN: $1596-5996$ (print); 1596-9827 (electronic)

(C) Pharmacotherapy Group, Faculty of Pharmacy, University of Benin, Benin City, 300001 Nigeria.

Available online at http://www.tjpr.org

Original Research Article

http://dx.doi.org/10.4314/tjpr.v19i6.10

\title{
Effects of icariin and quercetin on high glucose-induced neuronal cell apoptosis
}

\author{
Mengqian Dong, Ying Jin, Peifen Huang, Zhiyang Chen* \\ Department of Integrated Traditional Chinese and Western Medicine, The First People's Hospital of WenLing, Taizhou, PR \\ China \\ *For correspondence: Email: djnrs2@163.com
}

Sent for review: 16 March 2020

Revised accepted: 27 May 2020

\begin{abstract}
Purpose: To study the effects of icariin and quercetin on cell apoptotic changes in neurons induced by elevated glucose condition, and the mechanism involved.

Methods: Neonatal male Sprague Dawley rats $(n=48)$ weighing $5-7 \mathrm{~g}$ were used. Neuronal cells were isolated from rat hippocampus and cultured after purification. The cells were randomly assigned to six groups: control, high glucose, icariin, quercetin, serine/threonine-specific protein kinase (Akt) inhibitor, and Akt agonist groups. The Akt inhibitor and agonist used in this study were MK-22062hci and SC79, respectively. The influence of icariin and quercetin on neuronal apoptotic changes were determined flow cytometrically, while their effects on levels of expression of Akt, $p$-Akt, bax and bcl-2 were determined with Western blotting.

Results: Treatment with icariin or quercetin significantly inhibited apoptosis induced by high glucose. The concentrations of Akt, $p$-Akt, and bcl-2 proteins were markedly upregulated in high glucose group, relative to control $(p<0.05)$. The corresponding expression of bax was significantly down-regulated in high glucose group, relative to control $(p<0.05)$. Treatment with icariin or quercetin, or their agonists reversed high glucose-mediated alterations in these protein levels $(p<0.05)$.

Conclusion: Icariin and quercetin inhibit neuronal cell apoptosis induced by high glucose through upregulation of bcl-2 expression and down-regulations of bax expression and Akt-induced protein phosphorylation. Thus, Icariin and quercetin possess potential benefits for the treatment of neurological diseases.
\end{abstract}

Keywords: Apoptosis, High glucose condition, Hippocampal neurons, Icariin, Quercetin

\begin{abstract}
This is an Open Access article that uses a fund-ing model which does not charge readers or their institutions for access and distributed under the terms of the Creative Commons Attribution License (http://creativecommons.org/licenses/by/4.0) and the Budapest Open Access Initiative (http://www.budapestopenaccessinitiative.org/read), which permit unrestricted use, distribution, and reproduction in any medium, provided the original work is properly credited.
\end{abstract}

Tropical Journal of Pharmaceutical Research is indexed by Science Citation Index (SciSearch), Scopus, International Pharmaceutical Abstract, Chemical Abstracts, Embase, Index Copernicus, EBSCO, African Index Medicus, JournalSeek, Journal Citation Reports/Science Edition, Directory of Open Access Journals (DOAJ), African Journal Online, Bioline International, Open-J-Gate and Pharmacy Abstracts

\section{INTRODUCTION}

Diabetes mellitus (DM) is a mixed group of syndromes marked by elevated fasting blood glucose (FBG) due to relative or complete absence of insulin. In 2018, the global prevalence of type- 2 diabetes mellitus (T2DM) was about half a billion, thereby creating financial and psychological hardship for sufferers [1]. In 2015, the International Diabetes Union reported that more than 400 million people worldwide suffered from T2DM. The incidence of the disease increases on yearly basis, especially in developing countries [2]. Complications of DM are either microvascular or macrovascular, and some patients may suffer cognitive decline [3]. 
There is a direct relationship between the hippocampus and memory: neuronal information coding has been linked to memory loss, to some extent [4].

Although high glucose condition enhances the proliferation of adult neural progenitor cells, it poses serious threat to their survival [5]. Hippocampal neurons are involved in learning and memory. Persistent hyperglycemia, an important clinical manifestation of DM, inhibits proliferation of hippocampal neurons [6]. Chronic hyperglycemia causes neuronal damage and morphological alteration of hippocampal structure, thereby leading to cognitive impairment [7]. This is believed to be responsible for cognitive impairment and brain atrophy in patients with T2DM.

Icariin has been shown to possess pharmacological properties such as antitumor, immunomodulating and anti-apoptotic effects. Quercetin exerts anti-inflammatory, antihyperglycemic and anti-hypercholesterolemic properties, and effectively inhibits $\mathrm{H}_{2} \mathrm{O}_{2}$-induced neuronal and glial cell death [8].

The serine/threonine-specific protein kinase (Akt) exists at the intersection of many signal pathways, and is involved in cell viability, while inhibiting cell apoptosis [9]. Studies have reported the involvement of bcl-2 and bax in apoptosis [10]. This investigation was focused on the influence of icariin and quercetin on neuronal cell apoptosis induced by high glucose condition, and the possible mechanisms involved.

\section{EXPERIMENTAL}

\section{Materials}

Icariin was obtained from Hubei Jiangmin Taihua Chemical Co. Ltd. (China), while quercetin was purchased from Hubei Yuancheng saichuang Technology Co. Ltd. (China). Serine/threoninespecific kinase (Akt) inhibitor (MK-22062hci) and SC79 were products of Selleck (China). This research received approval from the Animal Ethical Committee of The First People's Hospital of WenLing (with approval number of 20198731), and was performed according to guidelines of "Principles of Laboratory Animal Care" (NIH article no. 85-23, 1985) [11].

\section{Rats}

Newborn male Sprague Dawley rats $(n=48)$ weighing $5-7 \mathrm{~g}$ (mean weight $=5 \pm 2 \mathrm{~g}$ ) were bought from Beijing Weitong Lihua Experimental Animal Technology Co. Ltd (no scxk 2018-0010).
The animals were housed in an aseptic environment with equal light/dark photoperiod at $25{ }^{\circ} \mathrm{C}$ and $50 \%$ relative humidity. They were acclimatized to laboratory condition for seven days before commencement of study, and had free access to standard feed and clean drinking water.

\section{Isolation of rat hippocampus and grouping of cells}

The hippocampi of the rats were isolated and cultured after purification in Dulbecco's modified Eagle medium (DMEM) for 3 days at $37^{\circ} \mathrm{C}$ in an atmosphere of $5 \% \mathrm{CO}_{2}$. The medium was refreshed every 2 days. Cells at logarithmic growth phase were used in the study.

The cultured hippocampal neurons were then randomly assigned to six groups: control, high glucose, icariin, quercetin, Akt inhibitor, and Akt agonist groups. The Akt inhibitor and agonist used in this study were MK-22062hci and SC79, respectively. With the exception of control group, the cells were treated with either glucose, icariin, quercetin, MK-22062hci or SC79. The effects of the different treatments on neuronal cell apoptosis, and levels of expression of various proteins were determined using flow cytometry and Western blotting, respectively.

\section{Determination of apoptosis}

The cultured hippocampal cells were in 6-well plates at $\left(2.5 \times 10^{6}\right.$ cells/well $)$ and cultured for 24 h. They were treated with either glucose, icariin, quercetin, MK-22062hci or SC79, and the medium was thereafter incubated for another 72 h, washed with phosphate-buffered saline (PBS), and properly blended with $300 \mu \mathrm{L}$ binding buffer. This was followed with staining in the dark using Annexin V-fluorescein isothiocyanate and PI (5 $\mu \mathrm{L}$ each) within $25 \mathrm{~min}$, and flow cytometric analysis for apoptosis at $485 \mathrm{~nm}$.

\section{Western blotting}

The cells were rinsed with PBS, and lysed using ice-cold RIPA buffer laced with protease inhibitor. The resultant lysate was subjected to centrifugation, and the protein content of the supernatant was measured using bicinchoninic acid assay kits. Then, protein $(30 \mu \mathrm{g})$ was resolved with SDS-PAGE, and transferred to PVDF membrane for $120 \mathrm{~min}$. The membrane was incubated with non-fat milk solution to block non-specific interaction of the blot. Thereafter, the membrane was subjected to incubation for 12 $\mathrm{h}$ at $4^{\circ} \mathrm{C}$ with $1^{\circ}$ antibodies for Akt, p-Akt, bcl-2, bax and $\beta$-actin, each diluted 1 to 1000 . Then, 
the membrane was washed thrice with TBS-T, followed by incubation with HRP-conjugated secondary antibody for $90 \mathrm{~min}$. x-ray films were applied in development of the blots, while Bio-rad gel imaging technique was used for Grayscale analysis of bands. $\beta$-Actin served as housekeeping gene.

\section{Statistics}

Data are shown as mean \pm SEM. The results were statistically analyzed with SPSS ver. 19.0. Group comparison was done with Student $t$-test. Statistical significance of differences was fixed at $p<0.05$.

\section{RESULTS}

\section{Effect of icariin and quercetin on neuronal cell apoptosis}

The population of apoptotic cells was markedly higher in high glucose group than in control, but it was markedly decreased following exposure to icariin, quercetin, MK-22062hci or SC79 ( $p<$ $0.05)$. Apoptosis was comparable amongst the treatment groups $(p>0.05$; Table 1$)$.

Table 1: Neuronal cell apoptosis in the various treatment groups

\begin{tabular}{lc}
\hline Group & $\begin{array}{c}\text { Level of neuronal } \\
\text { apoptosis (\%) }\end{array}$ \\
\hline Control & 11.68 \\
High glucose & 24.57 \\
Icariin & 15.83 \\
Quercetin & 15.73 \\
Icariin + MK-22062hci & 19.58 \\
Quercetin + MK-22062hci & 18.77 \\
SC79 & 15.68 \\
\hline
\end{tabular}

\section{Effect of icariin on expressions of p-Akt and Akt}

As presented in Table 2 and Figure 1, the expressions of Akt and p-Akt in high glucose group were significantly down-regulated, relative to control group, but were significantly upregulated after treatment with icariin or SC79 $(p<0.05)$. Protein expressions of Akt and p-Akt were significantly higher in icariin group than in icariin + MK-22062hci cells. Similarly, Akt and pAkt expressions were markedly higher in SC79 group than in icariin-treated cells.

\section{Effect of icariin on expressions of bcl-2 and bax}

The expressions of bcl-2 and bcl-2/bax were markedly decreased in high glucose group, while bax protein expression was markedly upregulated, relative to control. The bcl-2 level, and $\mathrm{bcl}-2 / \mathrm{bax}$ ratio were markedly elevated in icariin and SC79-treated cells, relative to high glucose-treated cells $(p<0.05)$. However, corresponding bax protein levels were markedly lower in icariin and SC79 groups than in high glucose group. Moreover, in icariin-treated cells, the proportion of bcl-2:bax was markedly higher than that in icariin + MK-22062hci group, while the corresponding bax expression was significantly lower than that in icariin $+\mathrm{MK}$ 22062hci-treated cells. However, no marked differences were seen in bcl-2 level, and bcl2/bax ratio between icariin and SC79 groups (Table 3 and Figure 1).

Table 2: Levels of expression of Akt and p-Akt in the various treatment groups

\begin{tabular}{lcc}
\hline Group & p-AKT & AKT \\
\hline Control & $118.69 \pm 0.34$ & $92.03 \pm 0.14$ \\
High glucose & $100.73 \pm 0.58$ & $81.38 \pm 0.02$ \\
Icariin & $107.00 \pm$ & $113.82 \pm$ \\
Icariin + MK- & $1.61^{\mathrm{ac}}$ & $1.61^{\mathrm{ac}}$ \\
$22062 \mathrm{hci}$ & $88.05 \pm 0.55^{\mathrm{b}}$ & $84.47 \pm 0.55^{\mathrm{b}}$ \\
$\mathrm{SC} 79$ & $128.21 \pm$ & $127.60 \pm$ \\
& $0.98^{\mathrm{a}}$ & $0.18^{\mathrm{a}}$ \\
\hline a, b, $\mathrm{c} P<0.05\left(^{\mathrm{a}} \mathrm{vs}\right.$ high glucose; ${ }^{\mathrm{b}} \mathrm{vs}$ icariin; $\left.{ }^{\mathrm{c}} \mathrm{Vs} \mathrm{SC79}\right)$
\end{tabular}

Table 3: Effects of icariin and its agonist and inhibitor on the expressions of bax and bcl-2

\begin{tabular}{lccc}
\hline Group & Bcl-2 & Bax & Bcl-2/Bax \\
\hline Control & $93.08 \pm$ & $73.82 \pm$ & $121.93 \pm$ \\
& 0.08 & 0.03 & 0.11 \\
High glucose & $89.04 \pm$ & $92.39 \pm$ & $96.48 \pm$ \\
& 0.09 & 0.11 & 0.04 \\
Icariin & $99.86 \pm$ & $82.85 \pm$ & $120.67 \pm$ \\
Icariin + MK- & $79.12^{\mathrm{ac}}$ & $0.03^{\mathrm{ac}}$ & $0.16^{\mathrm{ac}}$ \\
22062hci & $0.13^{\mathrm{b}}$ & $102.00 \pm$ & $77.82 \pm$ \\
SC79 & $102.60 \pm$ & $82.64 \pm$ & $124.29 \pm$ \\
& $0.58^{\mathrm{b}}$ & $0.69^{\mathrm{a}}$ & $1.00^{\mathrm{a}}$ \\
\hline
\end{tabular}

$\mathrm{a}, \mathrm{b},{ }^{c} P<0.05\left({ }^{\mathrm{a}} \mathrm{vs}\right.$ high glucose; ${ }^{\mathrm{b}} \mathrm{vs}$ icariin; ${ }^{\mathrm{c}} \mathrm{vs}$ MK22062hci)

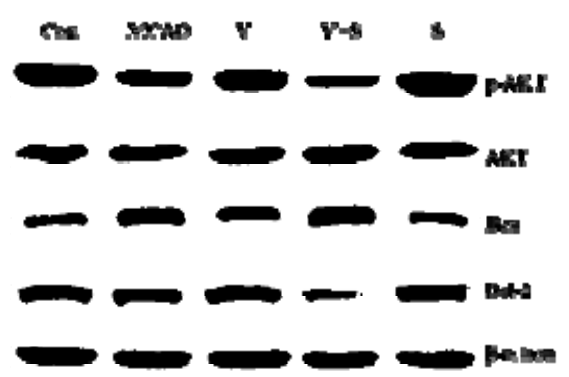

Figure 1: Akt, p-Akt, bcl-2 and bax levels in the various groups. Con: control; MCAO: high glucose; $\mathrm{Y}$ : icariin group; Y + S: icariin + MK-22062hci; S: MK22062hci 


\section{Effect of quercetin on expressions of Akt and p-Akt proteins}

The expression levels of Akt and p-Akt proteins were markedly decreased in high glucose group, relative to control group, but they were markedly upregulated in quercetin group, relative to high glucose group, and were significantly downregulated in quercetin + MK-22062hci group, when compared to control. The expressions of these genes were significantly upregulated by quercetin, when compared with SC79 $(p<0.05$; Table 4$)$.

Table 4: Levels of expression of Akt and p-Akt in the various treatment groups

\begin{tabular}{|c|c|c|}
\hline Group & p-AKT & AKT \\
\hline Control & $68.35 \pm 0.39$ & $90.45 \pm 0.24$ \\
\hline High glucose & $36.33 \pm 0.03$ & $78.31 \pm 0.27$ \\
\hline Quercetin & $59.26 \pm 0.42^{a}$ & $84.46 \pm 0.47^{a}$ \\
\hline $\begin{array}{l}\text { Quercetin + MK- } \\
22062 \mathrm{hci}\end{array}$ & $55.72 \pm 0.24$ & $75.37 \pm 0.28$ \\
\hline SC79 & $71.55 \pm 0.71^{b}$ & $101.49 \pm 0.80^{b}$ \\
\hline
\end{tabular}

\section{Levels of expression of bax and bcl-2}

The bcl-2 level, and bcl-2/bax were markedly decreased in high glucose group, relative to control $(p<0.05)$. However, their corresponding levels were markedly increased in quercetin group, relative to high glucose-treated cells. The $\mathrm{bcl}-2$ protein, and $\mathrm{bcl}-2 / \mathrm{bax}$ were also markedly lower in quercetin + MK-22062hci group, relative to high glucose group, and their concentrations were markedly smaller in quercetin group than in SC79-exposed cells. These results are shown below.

Table 5: Effect of quercetin and its agonist and inhibitor on concentrations of bax and bcl-2

\begin{tabular}{|c|c|c|c|}
\hline Group & Bcl-2 & Bax & $\begin{array}{l}\text { Bcl- } \\
\text { 2/Bax }\end{array}$ \\
\hline Control & $\begin{array}{c}117.26 \pm \\
1.67\end{array}$ & $\begin{array}{c}70.67 \pm \\
0.54\end{array}$ & $\begin{array}{c}166.12 \pm \\
1.62\end{array}$ \\
\hline High glucose & $\begin{array}{l}83.15 \pm \\
0.45\end{array}$ & $\begin{array}{c}89.00 \pm \\
0.09\end{array}$ & $\begin{array}{c}94.48 \pm \\
0.44\end{array}$ \\
\hline Quercetin & $\begin{array}{c}89.25 \pm \\
0.93^{\mathrm{ac}}\end{array}$ & $\begin{array}{c}73.25 \pm \\
0.34^{\mathrm{ac}}\end{array}$ & $\begin{array}{c}121.99 \pm \\
1.26^{\mathrm{ac}}\end{array}$ \\
\hline $\begin{array}{l}\text { Quercetin + MK- } \\
\text { 22062hci }\end{array}$ & $\begin{array}{l}80.14 \pm \\
0.56^{\mathrm{b}}\end{array}$ & $\begin{array}{c}86.99 \pm \\
0.35^{\mathrm{b}}\end{array}$ & $\begin{array}{c}92.23 \pm \\
0.42^{\mathrm{b}}\end{array}$ \\
\hline SC79 & $\begin{array}{c}104.19 \pm \\
1.50^{\mathrm{a}}\end{array}$ & $\begin{array}{c}81.48 \pm \\
0.77^{\mathrm{a}}\end{array}$ & $\begin{array}{c}128.01 \pm \\
1.02^{\mathrm{a}}\end{array}$ \\
\hline
\end{tabular}

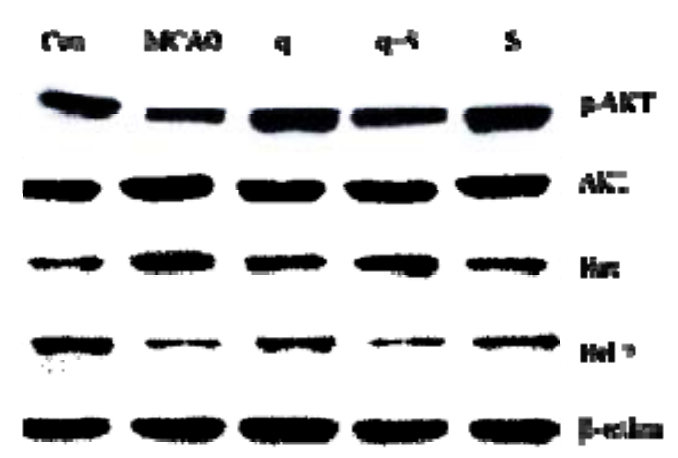

Figure 2: Levels of Akt, p-Akt, bcl-2 and bax in various groups. Con: Control; MCAO: High glucose; q: Quercetin; q + S: Quercetin + MK-22062hci; S: MK22062hci

\section{DISCUSSION}

Apoptosis, which is important in the growth of multicellular organisms via maintenance of their internal and external environment, has been implicated in the pathophysiology of T2DM. Chronic hyperglycemia promotes apoptosis, thereby leading to cognitive dysfunction [12].

It is known that PKB or Akt is involved in regulation of cellular events such as transcription, carbohydrate metabolism, apoptosis, as well as cell proliferation and migration. It has been shown to mediate the survival of neurons. Dysregulation of this protein produces stress-induced pathological and degenerative disorders which are related to the pathogenesis of a variety of neurological diseases. Studies have shown that Akt is involved in bcl-2/bax-dependent apoptotic pathway, and plays a crucial role in neuronal cell apoptosis [13].

In Traditional Chinese Medicine (TCM), "Bushen Huoxue Recipe" functions in tonifying the kidney and benefiting essence. It has shown potential in improving learning and memory function of mice with cerebral ischemia [14]. Epimedium tonifies the kidney, strengthens Yang, eliminates wind and dehumidifies, and is used in TCM to treat infertility and polyuria [15]. Icariin, a flavonoid glycoside compound, is the active principle in epimedium. Cuscuta is a genus of about $100-$ 170 species of yellow, orange, or red parasitic plants. Extracts and isolates from the plants have been shown to nourish the liver and kidney. They possess antioxidant and antitumor properties. Quercetin, a plant flavonol from the flavonoid group of polyphenols, is a bioactive compound present in Cuscuta [16]. 
The present study involved investigation of the effects of icariin and quercetin on neuronal cell apoptotic changes induced by high glucose, and the likely associated mechanism. The findings revealed that icariin and quercetin significantly inhibited neuronal cell apoptosis promoted by high glucose state. Treatment in the presence of Akt inhibitor (MK-22062hci) produced a similar effect. These results suggest that long-term high blood glucose level may induce apoptosis in neurons, thereby adversely affecting hippocampal function and memory.

It is likely that icariin and quercetin are potential inhibitors of high glucose-mediated apoptotic lesions in hippocampal neuronal cells. The results obtained from Western blotting indicate that the expressions of PKB, p-PKB, and bcl-2, and $\mathrm{bcl}-2 / \mathrm{bax}$ were markedly lower in high glucose group than in control, but the corresponding expression of bax was markedly higher in high glucose group than in control. The expressions of these genes were significantly higher in icariin group than in high glucose group. However, bax expression was significantly downregulated in high glucose group, relative to control. The expressions of Akt, p-Akt and bcl-2, and bcl-2/bax were higher in icariin group than in icariin + MK-22062hci group, but the corresponding bax protein expression was significantly reduced, relative to icariin $+\mathrm{MK}-$ 22062hci group.

These results show that icariin and quercetin may be effective in reversing high glucoseinduced Akt protein phosphorylation, and are in agreement with results of previous studies $[9,10]$. Inhibition of Akt pathway may have significantly reduced the protective effect of these compounds on neuronal cell apoptosis, an indication that they exerted their effects via the Akt pathway.

\section{CONCLUSION}

Icariin and quercetin inhibit neuronal cell apoptosis induced by conditions of high glucose through upregulation of bcl-2 expression, and downregulations of bax and Akt-induced protein phosphorylation. These findings have potential for use in the development of new drugs for the management of neurological diseases.

\section{DECLARATIONS}

\section{Conflict of interest}

No conflict of interest is associated with this work.

\section{Contribution of authors}

This study was done by the authors named in this article, and the authors accept all liabilities resulting from claims which relate to this article and its contents. The study was conceived and designed by Mengqian Dong; Mengqian Dong, Ying Jin, Peifen Huang, Zhiyang Chen collected and analyzed the data; Zhiyang Chen wrote the text. All authors read and approved the manuscript for publication.

\section{Open Access}

This is an Open Access article that uses a funding model which does not charge readers or their institutions for access and distributed under the terms of the Creative Commons Attribution License (http://creativecommons.org/licenses/by/ 4.0) and the Budapest Open Access Initiative (http://www.budapestopenaccessinitiative.org/rea d), which permit unrestricted use, distribution, and reproduction in any medium, provided the original work is properly credited.

\section{REFERENCES}

1. Vionnet N, Hani EH, Dupont S, Gallina S, Francke S, Dotte S, De Matos F, Durand E, Leprêtre F, Lecoeur C, et al. Genome-wide search for type 2 diabetessusceptibility genes in French whites: evidence for a novel susceptibility locus for early-onset diabetes on chromosome 3q27-qter and independent replication of a type 2-diabetes locus on chromosome 1q21-q24. Am J Hum Genet 2017; 67(6): 1470-1480.

2. Rawshani A, Rawshani A, Franzén S, Eliasson $B$, Svensson AM, Miftaraj M, McGuire DK, Sattar N, Rosengren A, Gudbjörnsdottir S. Mortality and Cardiovascular Disease in Type 1 and Type 2 Diabetes. N Engl J Med 2017; 376(15): 1407-1418.

3. Pruijm M, Wuerzner G, Maillard M, Bovet P, Renaud C, Bochud M, Burnier M. Glomerular hyperfiltration and increased proximal sodium reabsorption in subjects with type 2 diabetes or impaired fasting glucose in a population of the African region. Nephrol Dial Transplant 2010; 25(7): 2225-2230.

4. Michael PC. Insulin action and resistance in obesity and type 2 diabetes. Nat Med 2017; 23(7): 804-814.

5. Kim M, Jung K, Kim IS, Lee IS, Ko Y, Shin JE, Park KI. TNF- $\alpha$ induces human neural progenitor cell survival after oxygen-glucose deprivation by activating the NFKB pathway. Exp Mol Med 2018; 50(4): 14-25.

6. Zhang N, Yang S, Wang $C$, Zhang J, Huo L, Cheng Y, Wang C, Jia Z, Ren L, Kang L, et al. Multiple target of hAmylin on rat primary hippocampal neurons. Neuropharmacology 2017; 113(1): 241-251.

7. J Ni JN, Shi J, Zhang XK, Yang YC, Liu XM, Wei MQ, Li $T$, Wang PW, Tian JZ, Wang YY. Effect of GAPT Extract 
on Expression of Tau Protein and Its Phosphorylation Related Enzymes in Hippocampal Neurons of APPV717I Transgenic Mice. Chin J Integr Med 2017; 23(8): 605-610.

8. Li S, Yuan S, Zhao Q, Wang B, Wang X, Li K. Quercetin enhances chemotherapeutic effect of doxorubicin against human breast cancer cells while reducing toxic side effects of it. Biomed Pharmacother 2018; 100: 441447.

9. Guoyin Z, Hao P, Min L, Wei G, Zhe C, Changquan L. Antihepatocarcinoma Effect of Portulaca oleracea $L$. in Mice by PI3KJAkt/mTOR and Nrf2/HO-1/NF- $k B$ Pathway. Evid Based Complement Alternat Med 2017; 2017(1): 1-11.

10. Xie ZY, Xiao ZH, Wang FF. Hepatitis C Virus Nonstructural 5A Protein (HCV-NS5A) Inhibits Hepatocyte Apoptosis through the NF-kappab/miR503/bcl-2 Pathway. Mol Cells 2017; 40(3): 202-208.

11. World Health Organization. Principles of laboratory animal care. WHO Chron 1985; 39: 51-56.

12. Rehman MB, Tudrej BV, Soustre J, Buisson $M$, Archambault $P$, Pouchain $D$, Vaillant-Roussel $H$, Gueyffier F, Faillie JL, Perault-Pochat MC, et al. Efficacy and safety of DPP-4 inhibitors in patients with type 2 diabetes: Meta-analysis of placebo-controlled randomized clinical trials. Diabetes Metab 2017; 43(1): 48-58.

13. Kim W, Yang HJ, Youn $H$, Yun YJ, Seong KM, Youn B. Myricetin inhibits Akt survival signaling and induces Bad-mediated apoptosis in a low dose ultraviolet (UV)B-irradiated HaCaT human immortalized keratinocytes. J Radiat Res 2010; 51(3): 285-296.

14. Park BK, Lee JH, Seo HW, Oh KS, Lee JH, Lee BH. Icariin protects against radiation-induced mortality and damage in vitro and in vivo. Int J Radiat Biol 2019; 95(8): 1-27.

15. Galleggiante V, De Santis S, Cavalcanti E, Scarano A, De Benedictis M, Serino G, Caruso ML, Mastronardi M, Pinto A, Campiglia $P$, et al. Dendritic Cells Modulate Iron Homeostasis and Inflammatory Abilities Following Quercetin Exposure. Curr Pharm Des 2017; 23(14): 2139-2146.

16. He L, Wang X, Kang N, Xu J, Dai N, Xu X, Zhang H. MiR375 inhibits the hepatocyte growth factor-elicited migration of mesenchymal stem cells by downregulating Akt signaling. Cell Tissue Res 2018; 372(1): 1-16. 